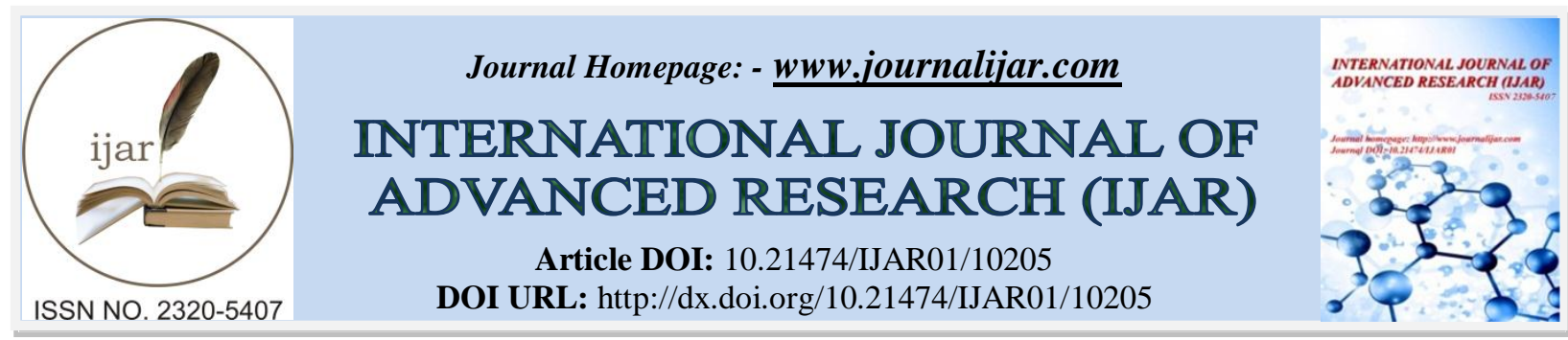

RESEARCH ARTICLE

\title{
ANTI - CANCER ENZYME(L - ASPARAGINASE) PRODUCTION, PURIFICATION AND CHARACTERIZATION FROM A SOIL ISOLATE OF PSEUDOMONAS SP
}

\author{
Narendra Kumar $\mathbf{S}^{1}$, Mohammed Haseeb Nawaz ${ }^{1}$, Shyam Shankar Mishra ${ }^{1}$, Satya Suman ${ }^{1}$, Lingayya \\ Hiremath $^{1}$, Praveen Kumar Gupta ${ }^{1}$, Ajeet Kumar Shrivastava ${ }^{1}$ and Mahesh $\mathbf{M}^{\mathbf{2}}$ \\ 1. Department of Biotechnology, R.V. college of Engineering, Bengaluru, India. \\ 2. Azyme Biosciences Private Limited, 1188/20, 3rd Floor, 26th Main, 9th Block, Jaya Nagar, Bengaluru 560069.
}

\section{Manuscript Info}

Manuscript History

Received: 10 October 2019

Final Accepted: 12 November 2019

Published: December 2019

Key words:-

L-Asparaginase, Pseudomonas Sp, Optimization, Purification, Lowry's Method, Characterization, Sds-Page

\section{Abstract}

L-Asparaginase or L-asparagine amido hydrolases are enzymes that catalyze the substrate hydrolysis of L-asparagine. It results in the formation of $\mathrm{L}$-aspartate and ammonia. It has immense application in the treatment of lymphoblastic leukemia as an antineoplastic agent and also finds its use in food technology. Its vast application in the pharmaceutical industry has led to the need for more sources of production of L-asparaginase. The current work is focused on production, purification, and characterization of L-asparaginase. The enzyme is produced using the batch mode of cultivation with critical media components disodium phosphate $(0.042 \mathrm{M})$, sodium chloride $(0.0854 \mathrm{M})$ and Asparagine $(0.060 \mathrm{M})$ respectively. The extracellular Lasparaginase was later purified by the following techniques: salt dialysis, ion-exchange chromatography, and gel filtration chromatography. Meanwhile, protein estimation was done using lowry's method. The molecular weight of the enzyme was found to be at $55 \mathrm{KDa}$ as revealed through SDS-PAGE. The biochemical analysis revealed that the species producing the enzyme belonged to Pseudomonas sp. The culture condition favoring the production of the enzyme L-asparaginase was found to be at a temperature of $40^{\circ} \mathrm{C}, \mathrm{pH}-$ 9 , and incubation time of $24 \mathrm{hr}$. Optimization with critical carbon and nitrogen sources with varying concentrations disclosed sucrose and ammonium sulfate at $1.5 \%(\mathrm{w} / \mathrm{w})$ to maximize the enzyme production. The purified enzyme was characterized by the above parameters $(400 \mathrm{C}$, $\mathrm{pH}-9)$ and incubation period of 40 minutes was found to be having an enzyme activity $434.10(\mathrm{U} / \mathrm{ml})$. Additionally, to overproduce the enzyme, strain development was performed with the treatment of UV-B rays exposed at different heights and $\mathrm{X}$-rays to yield more amount of enzyme.

Copy Right, IJAR, 2019,. All rights reserved.

\section{Introduction:-}

Erwinia and E. coli as potent sources of L-asparaginase has been described as a successful drug towards the treatment of acute lymphoblastic leukemia for a long time. However, these drugs are not entirely free from significant side effects. As a result, there is a remarkable need for safer and cost-effective sources for the production 
of the enzyme. L-asparaginases from a bacterial source although known for its therapeutic anti-tumor importance, they have been reported to lead to unfavorable allergic reactions and hypersensitivity in the long run. Although, sequential therapy with serologically unrelated asparaginase can be performed to avoid these immunological complications described above[3]. This has given a cue to find a diversity of asparaginases from different sources including fungi, basidiomycetes, and even small mammals such as hedgehogs. There is a check in the functional enzyme preparation for industrial/pharmaceutical applications due to the fact that the microbial sources used requires the presence of certain interfering proteins [2]. Balasubramanian et al., HPLC assay of enzyme activity for L-asparaginase and its molecular weight was determined as a characterization study of purified enzyme Lasparaginase. SDS page results revealed molecular weight of about $94 \mathrm{kDa}$.

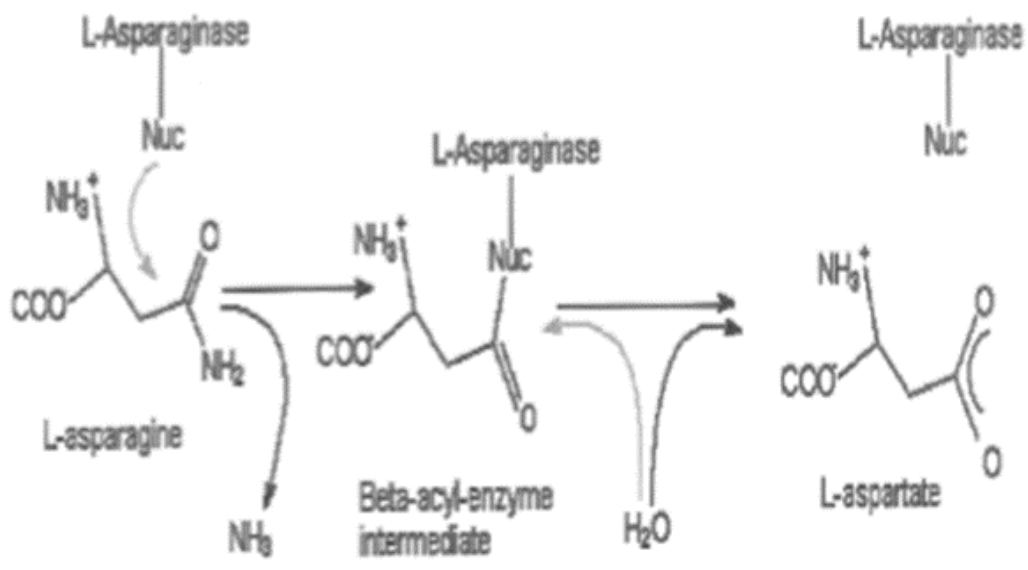

Fig 1:- Schematic illustration of reaction mechanism of 1-asparaginase.

\section{Materials And Methods:-}

Isolation and identification of microorganisms from the soil for production of L-Asparaginase

Collection of the soil sample:

Soil samples were collected from the Chennai industrial area, National Diary Research Institute Bengaluru and Kerur industrial area Bagalkot Karnataka.

\section{Screening the culture for l-asparaginase:}

The colonies formed in the pour plate method were isolated and cultured in the $\mathrm{m} 9$ medium agar plates by using streak plate method.

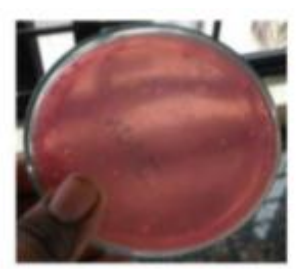

Colonies in the NORi sample

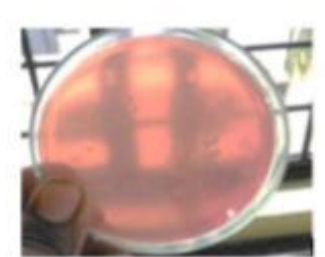

Colonies the kerur soll sample

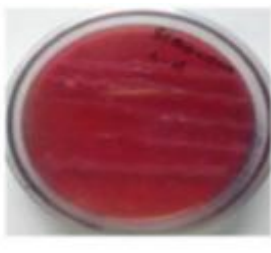

Screening of the Chennai sol sample

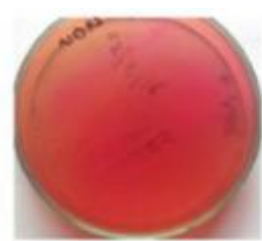

Screening of the NORI soll sarrple

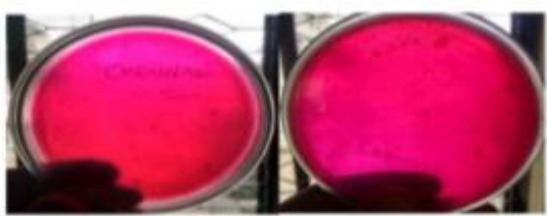

Colonies in the Chennai industrial Avee

Fig 2:- Collection and screening of NDRI soil sample, Kerur soil sample and Chennai industrial area soil sample. 


\section{Biochemical analysis:}

Gram staining: thin smears of the microorganisms were made on glass slide. Gram staining was then performed. The colonies were then observed under the microscope.

Biochemical tests performed : indole test, Voges Proskauer test, Citrate utilization test, Gelatin test, Hydrogen sulphide test, Triple sugar iron test, Methyl red test, Urease test, Casein hydrolysis test, Starch hydrolysis test, Lipid hydrolysis test, Cellulose degradation test, Glucose test, Sucrose test, Mannitol test, Lactose test, Catalase test, Oxidase test, Nitrate reduction test were performed. Gram staining revealed rod shaped colonies indicating gram negative bacteria.

Table 1:- Results of biochemical test.

\begin{tabular}{|l|l|l|}
\hline SI No & Biochemical-Tests & Test Results \\
\hline 1 & Indole & Negative \\
\hline 2 & Voges Proskauer & Negative \\
\hline 3 & Citrate utilization & Positive \\
\hline 4 & Gelatin & Positive \\
\hline 5 & Hydrogen sulphide & Negative \\
\hline 6 & Triple sugar iron & Negative \\
\hline 7 & Methyl red & Negative \\
\hline 8 & Urease & Negative \\
\hline 9 & Casein hydrolysis & Positive \\
\hline 10 & Starch hydrolysis & Negative \\
\hline 11 & Lipid hydrolysis & Positive \\
\hline 12 & Cellulose degradation & Negative \\
\hline 13 & Glucose & Positive \\
\hline 14 & Sucrose & Negative \\
\hline 15 & Mannitol & Negative \\
\hline 16 & Lactose & Negative \\
\hline 17 & Catalase & Positive \\
\hline 18 & Oxidase & Positive \\
\hline 19 & Nitrate reduction & Negative \\
\hline
\end{tabular}

\section{Analytical Studies:}

Enzymatic assay of L-Asparaginase (nesslerization method): Enzyme assay was performed to determine the organism with maximum enzyme production according to wriston and yellin (1973). The M9 media $\left(\mathrm{KH}_{2} \mathrm{PO}_{4}-3 \mathrm{~g} / \mathrm{l}\right.$, $\mathrm{Na}_{2} \mathrm{HPO}_{4}-6 \mathrm{~g} / \mathrm{l}, \mathrm{NaCl}-5 \mathrm{~g} / \mathrm{l}, \mathrm{NH}_{4} \mathrm{Cl}-2 \mathrm{~g} / \mathrm{l}, \mathrm{MgSO}_{4}-0.1 \mathrm{~g} / \mathrm{l}$, Asparagine-8g/l, Phenol red-0.005\%, Agar -20g/l pH-7.3 distilled water- 11) was prepared and each organism was inoculated separately and incubated for 24 hours. Meanwhile, UV- Visible spectrophotometer was used to perform the enzyme assay at $37^{\circ} \mathrm{C}$. The principle was based on finding the enzyme activity through catalysis of L-asparaginase by the Nessler's reagent which was directly proportional to the ammonia liberated in the reaction. The reaction mixture typically comprised of $0.05 \mathrm{M}$ Tris- $\mathrm{HCl}$ buffer and $0.01 \mathrm{M} \mathrm{L}$-asparagine. It was incubated at $37^{\circ} \mathrm{C}$ and a $\mathrm{pH}$ of 8.6 for a duration of 10 minutes. Additionally, $0.5 \mathrm{ml}$ of $15 \%$ trichloroacetic acid solution was added to end the reaction. At the end an ammonium sulphate reference was used as a standard which helped in the quantitative determination of the released ammonia.

\section{Optimization:-}

Optimizing the incubation time, $\mathrm{pH}$, Temperature, nitrogen an carbon sources and their concentration for enzyme production.

The organism was inoculated in the M9 media broth $(25 \mathrm{ml})$ and incubated for $24 \mathrm{hrs}$ and $48 \mathrm{hrs}$ and $\mathrm{pH} 5,6,7,8,9,10$ and various temperatures of $27{ }^{\circ} \mathrm{C}, 30{ }^{\circ} \mathrm{C}, 35^{\circ} \mathrm{C} 40{ }^{\circ} \mathrm{C}$ and $45^{\circ} \mathrm{C}$. The enzyme assay was performed using nesslerization method. The obtained maximum enzyme activity conditions were used for further optimization. This was followed by $1 \%$ concentration of different nitrogen sources such as ammonium nitrate, peptone, tryptone, ammonium sulfate, gelatin, sodium nitrate which were added in each of 6 test samples and the M9 broth $(25 \mathrm{ml})$ was inoculated and incubated. The enzyme assay was performed through nesslerization method to find the best suitable nitrogen source. 
It was followed by similar steps with concentrations ranging between $(0.5 \%-3 \%)$ of the highest enzyme activity producing nitrogen source. Additionally, $1 \%$ concentration of different carbon sources- glucose, sucrose, mannitol, lactose, starch, cellulose was added in each of 6 test samples and the M9 broth(25ml) was inoculated and incubated.

The enzyme assay was performed through nesslerization method to find the best suitable carbon source for maximum enzyme production. It was followed by similar steps with concentrations ranging $(0.5 \%-3 \%)$ of carbon source with the highest enzyme activity and the concentration was then determined which was further used for optimization studies.
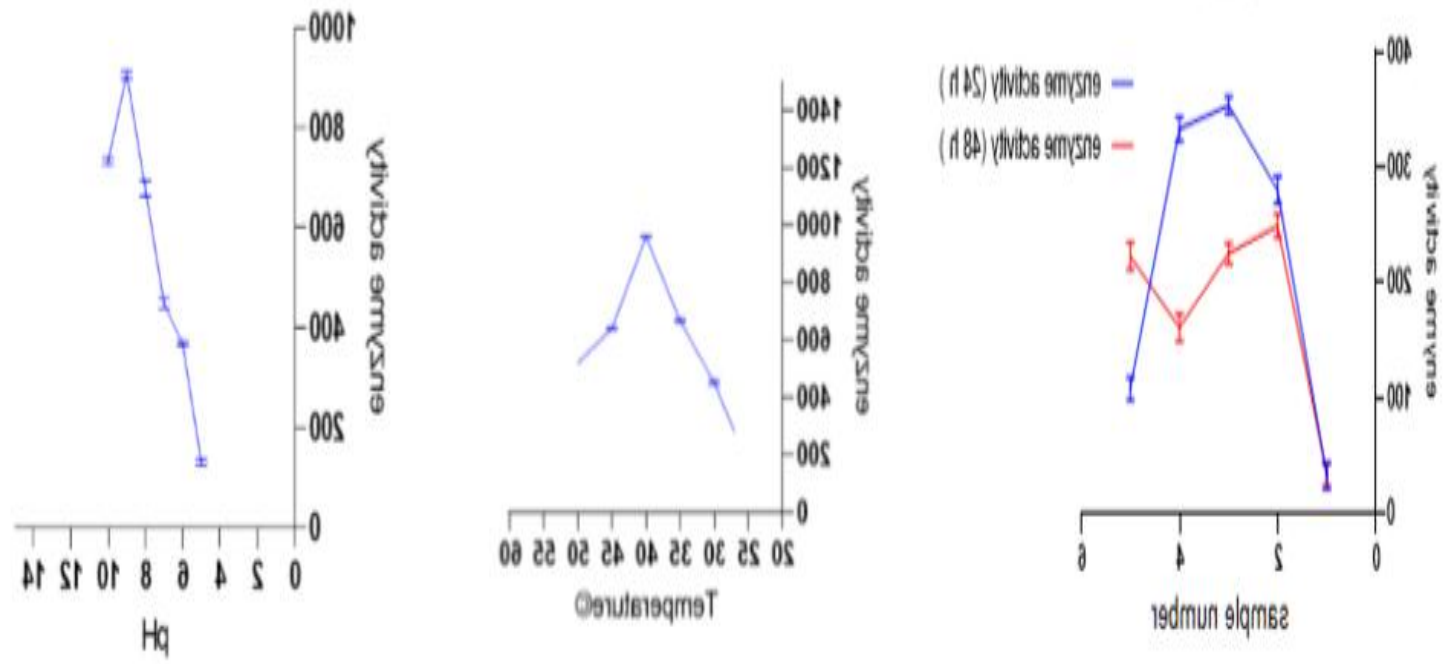

Graph 1:- Enzyme activity at different incubation time (24h ,48h), graph 2: Enzyme activity at different temperatures $\left(25^{\circ} \mathrm{C}-50^{\circ} \mathrm{C}\right)$, graph 3 : Enzyme activity at different $\mathrm{pH}(5-11)$.

a.
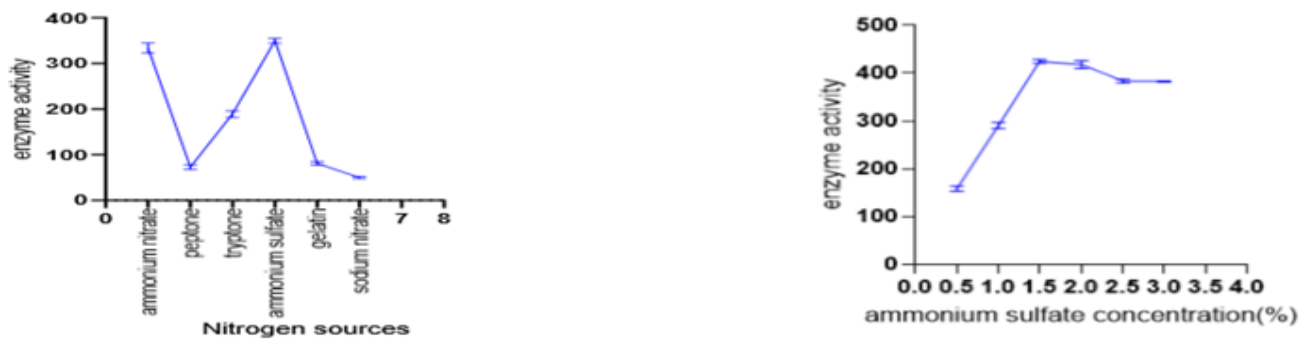

b.
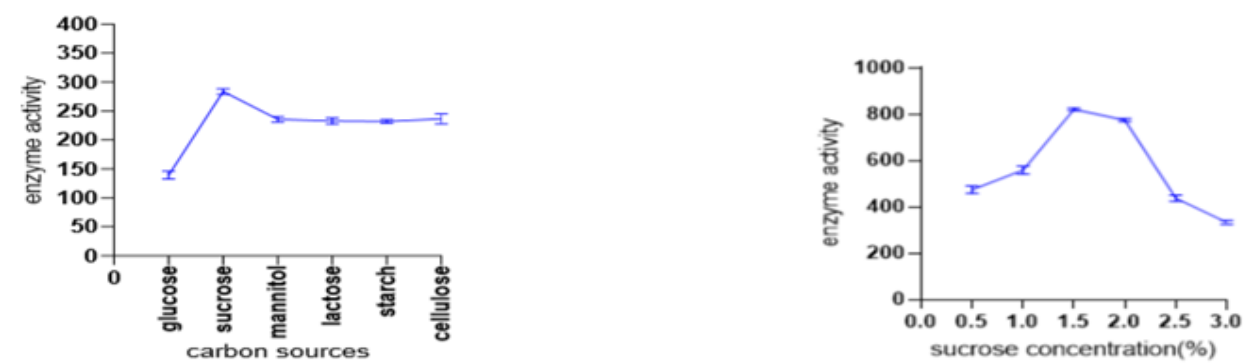

Fig 4:- a. Enzyme activity for different nitrogen sources and enzyme activity with different ammonium sulfate concentrations (0.5-3.0\%). b. Enzyme activity for different carbon sources and enzyme activity with different sucrose concentration $(0.5-3.0 \%)$. 


\section{Strain Development For Overproduction Of Enzyme:-}

Effect of UV-induced stress on the enzyme production: The inoculated LB agar plates were exposed to UV-B rays for $5 \mathrm{~min}, 10 \mathrm{~min}, 15 \mathrm{~min}, 20 \mathrm{~min}, 25 \mathrm{~min}$ respectively. The plates were incubated for 24 hours at $37{ }^{\circ} \mathrm{C}$ at a distance of $55 \mathrm{~cm}$. After the incubation the enzyme assay was performed by the nesslerization method.

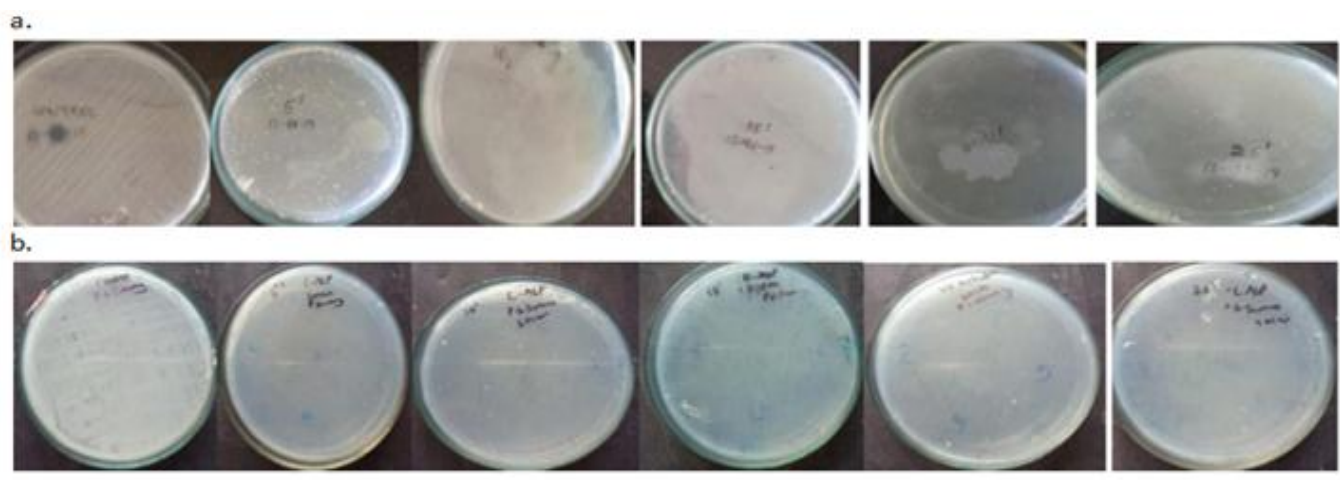

c.

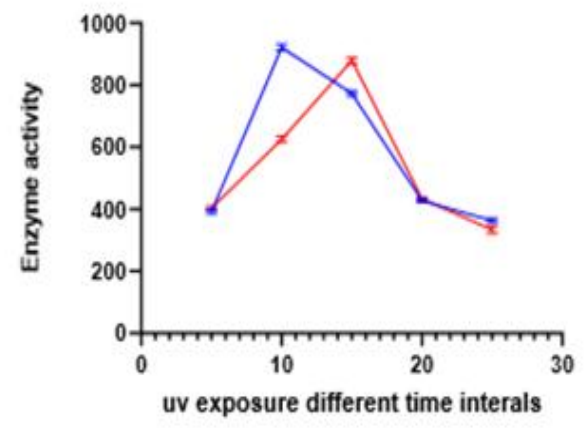

- enzyme activity(height
wise effect of UV Rays)
- enzyme activity for UV

Fig 5:- Control and samples for $5,10,15,20,25$ minutes of exposure to UV-B rays. b. height wise effect of exposure to UV rays for control, and samples for 5,10,15,20,25 minutes .effect of UV-B radiation and its height wise effect on enzyme activity.

Effect of height wise induced UV stress on the enzyme production:

The inoculated LB agar plates were exposed to UV-B rays for $5 \mathrm{~min}, 10 \mathrm{~min}, 15 \mathrm{~min}, 20 \mathrm{~min}, 25 \mathrm{~min}$ respectively. The plates were incubated for 24 hours at $37{ }^{\circ} \mathrm{C}$ at the distance of $20 \mathrm{~cm}$. The incubation was followed by enzyme assay

Effect of $\mathrm{x}$ rays on the enzyme production: The inoculated agar plates were exposed to grace period 30,60,90 minute respectively. The plates were incubated for 24 hours at $37^{\circ} \mathrm{C}$.After the incubation the enzyme assay was performed by the nesslerization method.
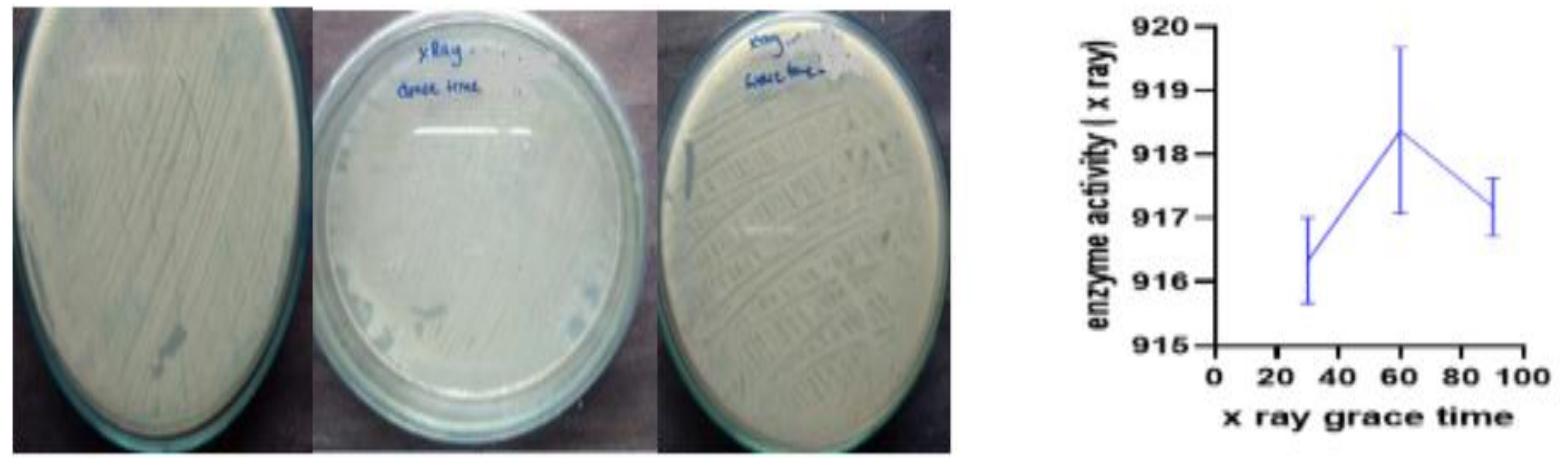

Fig 6:- Effect of X-radiation on enzyme activity on the microbial sample and its trend in the graph shown above when exposed to grace time of $30,60,90$ minutes of grace time. 


\section{Purification Of Enzyme:}

Salt Dialysis: The amount of salt to be added was measured according to the formula and salt purification was performed.

Amount of ammonium sulphate $(\mathrm{g})=(44 \mathrm{x}$ volume of supernatant $) / 100$. The membrane was then activated using $2 \%$ sodium bicarbonate(w/w). It was followed by diffusion of the sample for partial purification.

Ion Exchange chromatography: In 7 test tubes $250 \mu 1$ of tris $\mathrm{HCl}$ was added . And in test tube- 1 and test tube- 2 $250 \mu \mathrm{l}$ of $\mathrm{NaCl}$ was added to the remaining test tubes. $\mathrm{NaCl}$ was added with an increase of $250 \mu \mathrm{l}$ each. It was made up to $5 \mathrm{ml}$ by adding autoclave water. Elution- 1 was added to equilibrate DEAE cellulose in the ion exchange column, it was completely removed and then sample was added into the ion exchange tubes. Followed by addition of elution-2,3,4,5,6,7 and the samples were collected.

Estimation of protein: The method proposed by Lowry et al. (1951) was used for the determination of the amount of protein.

Gel Filtration Chromatography: The sephadex g-75 gel was poured into the gel filtration column, followed by the sample and f $0.1 \mathrm{M}$ phosphate buffer at $\mathrm{Ph} 7$. The sample were eluted in 25 Eppendorf tubes. The absorbance was measured at $280 \mathrm{~nm}$.

Table 2:- Protein purification chart.

\begin{tabular}{|l|l|l|l|l|l|}
\hline SAMPLE & $\begin{array}{l}\text { Enzyme activity (units } \\
/ \mathrm{ml})\end{array}$ & $\begin{array}{l}\text { Protein amount } \\
(\mathrm{mg} / \mathrm{ml})\end{array}$ & $\begin{array}{l}\text { Specific } \\
\text { activity (units } \\
/ \mathrm{mg})\end{array}$ & $\begin{array}{l}\text { Fold } \\
\text { purificatio } \\
\mathrm{n}\end{array}$ & $\begin{array}{l}\text { Percentage } \\
\text { yield }(\%)\end{array}$ \\
\hline Crude & 2191.98 & 4.803 & 456.37 & 1 & 100 \\
\hline Salt & 1679.58 & 1.808 & 928.97 & 2.036 & 76.62 \\
\hline Dialysis & 744.74 & 0.881 & 845.33 & 1.852 & 33.93 \\
\hline Ion exchange & 679.98 & 0.804 & 844.52 & 1.850 & 31.02 \\
\hline Gel filtration & 434.10 & 0.513 & 846.19 & 1.854 & 19.80 \\
\hline
\end{tabular}

SDS-PAGE: In 6 Eppendorf, 100 ul of salt, crude, dialysis, gel filtration, ion exchange and BSA samples were added. Followed by 50 microlitre SDS dye was added and the PAGE was run using standard gel and stacking gel setup.

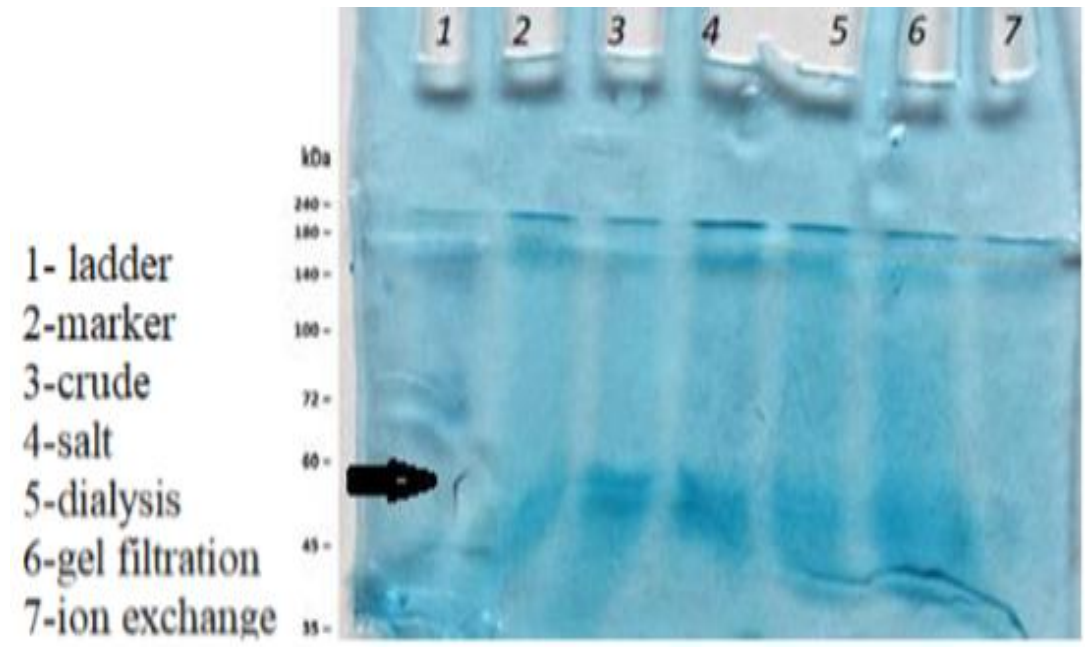

Fig 7:- SDS-PAGE result.

\section{Characterization Of Enzyme:}

Effect of $\mathrm{pH}$, temperature, incubation time and substrate concentration on the enzyme activity. The cell free extract was taken and the $\mathrm{pH}$ was adjusted for 4, 5, 6, 7, 8, 9 and different temperature such as 27, 30, 35, 40, 45 Celsius. Followed by different incubation time intervals 10, 20, 30, 40, 50 and 60 minutes. Additionally, substrate 
concentrations ranging $0.2 \%, 0.4 \%, 0.6 \%, 0.8 \%, 1.0 \%(\mathrm{w} / \mathrm{w})$ was used for characterization. Enzyme assay was performed through nesslerization method for each of the steps above and the enzyme was characterized.

a.

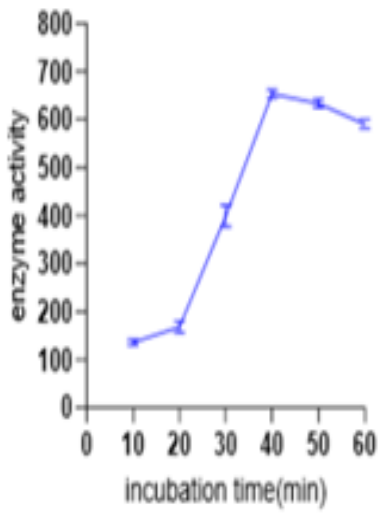

b.

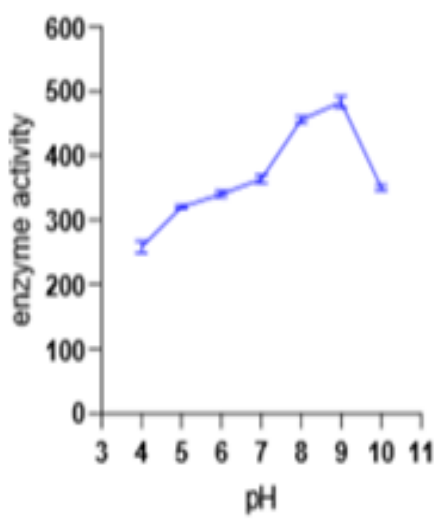

c.

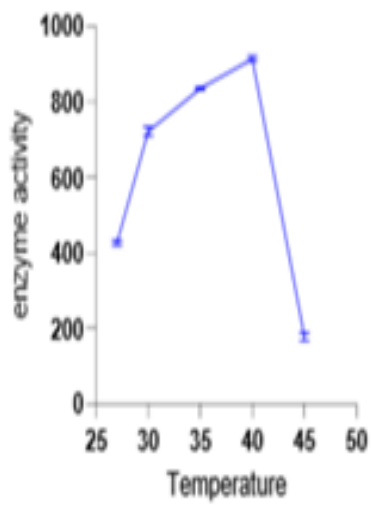

d.

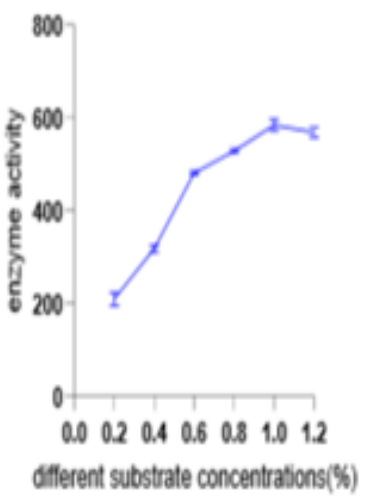

Fig 8:- Graph a: Effect of enzyme activity with different incubation time(minutes) Graph b: Effect of enzyme activity with different pH. Graph c: Effect of enzyme activity with different temperature (Celsius). Graph d: Effect of enzyme activity with different substrate concentration (\%).

\section{Results And Discussion:-}

The soil samples were collected from the Chennai industrial area, National Diary Research Institute Bengaluru and Kerur industrial area Bagalkot Karnataka. The bacterial strain was isolated on M9 agar media from these soil samples. The strains which produced L-Asparaginase were identified by pink-colored colony (Praksham et al. 2010).

The enzyme producing colony was selected for further studies (Chennai industrial area). The microbial strain was characterized by morphological and biochemical analysis. Microscope observation of the colony disclosed that the strain with rod-shaped colonies was gram-negative. The microbial strain was able to utilize citrate, liquify gelatin and hydrolyze casein and lipid. The strain also showed positive catalase and oxidase tests. Through these results, we identified the microorganism to belong to the Pseudomonas genus. The bacterial strain chosen elucidated a maximum growth at $24 \mathrm{~h}$ for the batch fermentation process and the maximum production of the enzyme was found to be at $24 \mathrm{~h}$ as well(fig 3). The enzymatic activity- $906.78 \mathrm{U} / \mathrm{ml}$ was observed at $\mathrm{pH} 9$ which was noted to be the optimum $\mathrm{pH}$ for maximum enzyme production (fig 3). The enzyme activity increased to $958.03 \mathrm{U} / \mathrm{ml}$ at $40^{\circ} \mathrm{C}$ (fig 3). Similar results were recorded at $\left(40^{\circ} \mathrm{C}\right)$ in studies done by [15] on pseudomonas aeruginosa. These conditions were used for further optimization studies. The strain development was performed using UV-B rays and X rays (fig 5,6). The enzyme activity increased when exposed to UV-B, hence we infer that exposure to UV-B created a mutation in the microbial strain thereby increasing the enzyme activity. Highest activity was found for the plate which was exposed to 15 minutes(enzyme activity-878.23 units $/ \mathrm{ml}$ ). When exposed to different time intervals with a distance of $10 \mathrm{~cm}$, plate which was kept for 10 minutes showed maximum enzyme activity(921.65 Units/ml)(fig 5).

However, $\mathrm{X}$ rays did not show any significant consequence on the enzyme activity and a decline in enzyme activity can be seen in the grace time 60 and 90 min (fig 6). Modified M9 media, when used with different carbon and nitrogen sources optimized with different concentrations showed maximum enzyme activity for sucrose (fig 4) and ammonium sulfate (fig 4) respectively. The trend of these carbon and nitrogen sources is evident in the (fig 4.a, fig 4.b) and it is clear the maximum production of the enzyme is at a concentration of $1.5 \%(\mathrm{w} / \mathrm{w})$ for each one of these sources. This was in line with the studies done by [22] for Pseudomonas sp. Ammonium sulfate precipitation, salt dialysis consecutively ion exchange chromatography and gel filtration chromatography was done for the purification of the enzyme. The purified enzyme was further used for characterization studies. The enzyme activity decreased from crude to gel filtration gradually this was in line with studies done by Ashraf et.al., 2003 Vidhya Moorthy et.al., 2010.The percentage yield of protein decreased up to $19.8 \%$ in the gel filtration and the fold purified up to 1.854 in gel filtration. The protein profiling to determine the molecular weight of the enzyme was done using SDS-PAGE. A protein band of a molecular weight of approximately $55 \mathrm{kDa}$ (Fig 7) was obtained. The study done by [9]Bacillus sp 
had a molecular weight of $55 \mathrm{kDa}$. Table 2 represents the protein purification trend from crude to gel filtration. The purified enzyme was then characterized with optimum $\mathrm{pH}$, temperature, incubation time and substrate asparagine concentration. The enzymatic activity of the purified enzyme gradually increased up to 40 minutes $(644 \mathrm{U} / \mathrm{ml})$ and then decreased on further increase in the incubation time (fig 8). The enzyme showed maximum activity at a pH 9472.51 U/ml (fig 8). A similar trend was found for enzyme activity at $40^{\circ} \mathrm{C}$ and decreased on further increase of temperatures (fig 8). The obtained results illustrated a gradual enzyme activity increase with increasing substrate concentration up to $1.20 \%$ substrate concentration (maximum enzyme activity for $1.20 \%$ concentration was 580.61 $\mathrm{U} / \mathrm{ml}$ ) as illustrate in fig 8.

\section{Conclusion:-}

The current study disclosed L-Asparaginase production from soil isolates of Pseudomonas sp. The purification was achieved through ion exchange chromatography and surplus salt was removed using dialysis. The enzyme was then characterized which showed the optimum $\mathrm{pH}$ found to be at 9. The enzyme had its maximum activity at a temperature of $40^{\circ} \mathrm{C}$ and an incubation time of about 40 minutes .6 different carbon and nitrogen sources were used for production among which sucrose and ammonium sulphate showed maximum enzyme activity. Exposure to UV$B$ rays had increased the enzyme activity. Highest activity was found for the plate which was exposed to 15 minutes (enzyme activity-878.23 units/ml). For height wise effect, when exposed to different time with a distance of $10 \mathrm{~cm}$, kept for 10 minutes showed maximum enzyme activity (Enzyme activity $921.65 \mathrm{Units} / \mathrm{ml}$ ). The X rays did not show any considerable effect on the enzyme. The high amount of catalytic activity along with remarkable stability over a comprehensive $\mathrm{pH}$ and temperature makes it a considerably good anti-cancerous agent. To sum up, L-Asparaginase from different microbial sources shows such properties which make it a potent enzyme for both pharmaceutical and industrial application. Future studies need to be performed in order to reduce the cost of enzyme production. This could be done by increasing the yield of L-asparaginase through optimization of the production process or by strain improvement. Although bacterial L-Asparaginase causes certain unfavorable reactions [14]. The purification and characterization studies on the enzyme would definitely open unexplored prospects in the health care industry[9]

\section{Conflict of Interest:}

There is no conflict of interest between any of the research personnel.

\section{Author's Contribution:}

All the Authors have made significant contributions towards the research manuscript.

\section{Funding (Clearly mention grant number, if any):}

There was no funding received from any of the authorities for the research project.

Data Availability:

The data has been taken from the lab work, also by referring to related research papers.

\section{Ethics Statement:}

There was no harm done to any animals and it involved none of the transgenic procedures which would be ethically wrong.

\section{Acknowledgement:-}

The authors listed in this paper wish to express their appreciation to the Azyme biosciences private limited Bangalore and RSST trust Bangalore for their continuous support and encouragement. As a corresponding author, I also express my sincere thanks to all other authors whose valuable contribution and important comments made this manuscript to this form. The authors listed in this paper have no conflict of interest known best from our side. There was also no problem related to funding. All authors have contributed equally with their valuable comments which made the manuscript to this form

\section{References:-}

1. Abuchowski, A., Kazo, G. M., Verhoest, C. R., "Cancer therapy with chemically modified enzymes. I. Antitumor properties of poly ethylene glycol-asparaginase"; Cancer Biochem. Biophys. 7:175-186,1984 
2. Ekpa Emmanuel., Nzelibe HCand Onyike E., "Isolation, Partial Purification and Characterization of LAsparaginase from Hedgehog Serum"; Journal of microbial and biochemical technology, Volume 7(6): 404-409 (7015) - 404,2015

3. Dodson G, Wlodawer A., "Catalytic trends and their relatives"; trends biochem and sci 23:347-352,1998

4. Kil JO, kim GN, park I., "extraction of extracellular 1-asparaginase from candida utilis" biosci biotechnol biochem 59:749-750,1985

5. Datar R., "economic of primary separation steps in relation to fermentation and engineering"; process biochem, 21:19-26,1986.

6. Arima, K..," Microbial enzyme production in Global Impact of Applied Microbiology"; M.P. Starr (eds.), pp. 279-299, 1964

7. Lonsane, B. K., Ghildyal, N. P., Budiatman, S. and Ramakrishnan,S. V. "Engineering aspects of solid-state fermentation". Enzyme Microb. Technol. 7, 228-256,1985.

8. Hill, J., Roberts, J., Loeb, E., Kahn, A. and Hill, R. "L-Asparaginase therapy for leukemia and other malignantneoplasm." JAMA 202, 882,1967.

9. Vidhya Moorthy, Aishwarya Ramalingam, Alagarsamy Sumantha and Rajesh Tippapur, Shankaranaya., "Production, purification and characterization of extracellular L-asparaginase from a soil isolate of Bacillus sp.”; African Journal of Microbiology Research, .Vol.4 (18), pp.1862-1867,2010.

10. Daoliang Li, Shuangyin Liu, in Water Quality Monitoring and Management, 2019

11. Amena S, Vishalakshi N, Prabhakar M, Dayanand A, Lingappa K., "Production, purification and characterization of L- asparaginase from Streptomyces gulbargensis"; Brazil J. Microbiol., 41: 173-178,2010

12. Dhevagi P, Poorani E.," Isolation and characterization of L- asparaginase from marine actinomycetes." Ind. J. Biotechnol., 5: 514- 520,2006.

13. Narayana KJP, Kumar KG, Vijayalakshmi M., "L-asparaginase production by Streptomyces albidoflavus." Ind. J. Microbiol., 48: 331- 336.2007.

14. Sadia Sanawer, Sikander Ali, Tahira Mohsin, Ammara Nasir (2017),Production, Purification and Advance Applications of L- Asparaginase (Review),International Journal of Scientific Research in Science and Technology 3; 341-351

15. S. Komathi, G. Rajalakshmi, S. Savetha and S. Balaji., "Isolation, production and partial purification of 1asparaginase from Pseudomonas aeruginosa by solid state fermentation";Sch. Acad. J. Pharm., 2(2):55-59.2013.

16. P. Sindhwad, K. Desai.,." Media Optimization, Isolation and Purification of L-Asparaginase from Marine Isolate"; Asian Pac. J. Health Sci.; 2(3):72-82,2015.

17. Manna S, Sinha A, Sadhukhan R and Chakrabarty SL., "Purification, characterization and antitumor activity of Lasparaginase isolated from Pseudomonas stutzeriMB-405”, Curr Microbiol,30,291-298,1995

18. Sobis M and Mikucki J.," Staphylococcal Asparaginase: Enzyme kinetics, "ActaMicrobiol. Pol, 40, 143-152. 1991

19. Roberts, J., Holcenberg, I. S. and Dolwy, W. C.," Crystallization and properties of Achromobacteriacae glutaminase, asparaginase with antitumor activity". J. Biolog. Chem. Vol. 247, pp.84-90,1972.

20. Castaman, G. and Rodeghiero, F. "Erwinia and E. coli derived L-asparaginase have similar effect on hemostasis". Hematologica. Vol.78, pp.57-60,1992.

21. Noura el-Ahmady el-nagar, Sahar F.Deraz, Sara M. El-Ewasy and Ghada M. Suddek.," purification characterization and immunogenicity assessment of glutaminase free L-asparaginase from streptomyces brollosae NEAE-115.”,2018.

22. Ashraf A. El-Bessoumy, Mohammed sarhan, Jehan Mansour., "production, isolation and purification of L asparaginase from pseudomonas aeruginosa 50071 using solid state fermentation"; journal of biochemistry and molecular biology, vol.37 pp.387-393,2013. 